\title{
Erratum to: Preface
}

\author{
Lorna J. Jaramillo-Nieves • Robert B. Finkelman
}

Published online: 2 March 2012

(C) Springer Science+Business Media B.V. 2012

\section{Erratum to: Environ Geochem Health DOI 10.1007/s10653-011-9432-0}

Unfortunately, the author's name has been published incorrectly in the original publication. The correct name should read Robert B. Finkelman.

The online version of the original article can be found under doi:10.1007/s10653-011-9432-0.

L. J. Jaramillo-Nieves $(\bowtie) \cdot$ R. B. Finkelman

San Juan, Puerto Rico

e-mail: lorna.jaramillo@upr.edu 